\title{
O GRUPO IBIÁ NA SINFORMA DE ARAXÁ: UM TERRENO TECTONOESTRATIGRÁFICO LIGADO À EVOLUÇÃO DE ARCOS MAGMÁTICOS
}

\author{
HILDOR JOSÉ SEER ${ }^{1}$, MARCEL AUGUSTE DARDENNE ${ }^{2}$, MARCIO MARTINS PIMENTEL ${ }^{2}$, \\ MARCO ANTONIO FONSECA ${ }^{3} \&$ LÚCIA CASTANHEIRA MORAES ${ }^{4}$
}

\begin{abstract}
THE IBIÁ GROUP IN THE ARAXÁ SYNFORM: A TECTONOSTRATIGRAPHIC TERRANE LINKED TO THE EVOLUTION OF MAGMATIC ARCS This paper adresses new provenance data on the Ibiá metasedimentary rocks from the Araxá synform. The stratigraphic type-section is located in Araxá region, at the southern segment of the Brasília Belt. The Araxá synform is a regional fold, with WNW trending limbs, dipping to NNE and SSW, with a WNW gently plunging hinge. The Araxá, lbiá and Canastra groups are exposed along the limbs of the Araxá synform. Each one of these groups is placed in three tectonic thrust sheets, separated one from each other by major, gently dipping and subvertical shear zones. The lower thrust sheet (Canastra Group) is a psamo-pelitic metasedimentary sequence, metamorphosed up to greenschist facies (chlorite and garnet zones) with $\mathrm{Sm}-\mathrm{Nd} \mathrm{T}$ model age of $2.2 \mathrm{Ga}$. It represents sediments deposited on a marine platform up to greenschist facies (chlorite and garnet zones) with $\mathrm{Sm}-\mathrm{Nd} \mathrm{T}_{\mathrm{DM}}$ motel age of $2.2 \mathrm{Ga}$. Iquepresents grading to a metasedimentary rock unit, both metamorphosed up to amphibolite facies conditions and cut by granitoid rocks. The metasedimentary rocks display Sm-Nd $\mathrm{T}$ model age of $1.9 \mathrm{Ga}$. In the intermediate thrust sheet, the Ibiá Group, a metapelitic sequence is composed by fine grained rhythmites. Their Sm-Nd T $\mathrm{T}_{\mathrm{DM}}$ model ages are between 1.1 and $1.3 \mathrm{Ga}$, and metamorphism reaches the chlorite zone of the greenschist facies. Petrographic and geochemical data support an origin due to erosional processes of Neoproterozoic magmatic arcs. Sediments were probably deposited from distal turbiditic currents in a back-arc basin. The Ibiá Group is so far interpreted as a tectonostratigraphic terrane, with unique stratigraphy and without genetic relationships to the adjacent Canastra and Araxá terranes.
\end{abstract}

Keywords: Brasília Belt, Ibiá Group, metassediments, provenance, Geochronology, Neoproterozoc, Magmatica Arcs

\begin{abstract}
RESUMO Neste trabalho são apresentados novos dados sobre a proveniência das rochas metassedimentares do Grupo Ibiá na sinforma de Araxá. A seção-tipo deste grupo está localizada na região de Araxá, que faz parte do segmento meridional da Faixa Brasília. A sinforma de Araxá é uma afloram as rochas dos grupos Araxá, lbiá e Canastra. Estes grupos estão estruturados em três lascas tectônicas, separadas entre si por zonas de afloram as rochas dos grupos Araxá, lbiá e Canastra. Estes grupos estão estruturados ementres A lasca tectônica inferior (Grupo Canastra) é uma sequência metassedimentar psamo-pelítica, metamorfisada em condiçôes de facies xisto verde (zonas da clorita até granada) com idades modelo $\mathrm{Sm}-\mathrm{Nd} \mathrm{T} \mathrm{T}_{\mathrm{DM}}=2,2 \mathrm{Ga}$. Ela representa sedimentos depositados em ambiente marinho plataformal. A lasca tectônica superior (Grupo Araxá) compreende uma sequência metaígnea máfica com transição para rochas metassedimentares, ambas metamorfisadas sob condições da fácies anfibolito e cortadas por rochas granitóides. As rochas metassedimentares apresentam idades modelo Sm- $\mathrm{Nd} \mathrm{T}_{\mathrm{D}}=1,9 \mathrm{Ga}$. Na lasca tectônica intermediária (Grupo Ibiá) uma sequência metasedimentar pelítica está arranjada em ritmitos finamente granulados. Tem idades modelo $\mathrm{Sm}-\mathrm{Nd} \mathrm{T}_{\mathrm{PM}}=1,1$ a $1,3 \mathrm{Ga}$ e foi metamorfisada sob fácies xisto verde (zona da clorita). Dados petrográficos e geoquímicos indicam que estes metassedmentos originaram-se a partir da erosão de arcos magmáticos. Os sedimentos foram provavelmente depositados por correntes de turbidez distais em uma bacia de retroarco. O Grupo Ibiá é interpretado como um terreno tectonoestratigráfico, com estratigrafia própria e sem relações genéticas com os terrenos vizinhos representados pelos Grupos Araxá e Canastra.
\end{abstract}

Palavras-chaves: Faixa Brasília, Grupo Ibiá, metassedimentos, proveniêrcia, Geocronologia, Arcos Magmáticos

INTRODUÇão A sinforma de Araxá (Fig. 1) se insere no setor meridional da Faixa de Dobramentos Brasília, que compreende um cinturão orogênico que evoluiu na borda oeste do Cráton do São Francisco durante o Neoproterozóico. Esta estrutura engloba unidades estratigráficas das zonas interna e externa da faixa, representadas pelos grupos Ibiá, Canastra e Araxá.

O presente estudo refere-se ao Grupo Ibiá, em sua área-tipo, situada na região dos municípios de Araxá e Ibiá, Estado de Minas Gerais, onde também foram definidos os grupos Araxá e Canastra (Barbosa 1955, Barbosa et al. 1970). A Formação Ibiá foi caracterizada por Barbosa et al. (1970) como sendo formada por calcixistos que ocorrem ao longo do rio Quebra-Anzol e nas proximidades da cidade de Ibiá.

Desde o trabalho destes autores, a região mereceu pouca atenção, sobretudo no que concerne a levantamentos geológicos de maior detalhe. Em vista disto, os conceitos estratigráficos originais foram aplicados e disseminados em toda a extensão da Faixa Brasília e mesmo até a Faixa Araguaia. Os poucos trabalhos posteriormente realizados, no entanto, (e.g. Paulsen et al. 1974, Ferrari 1989, Besang et al. 1977) colocam em dúvida a validade de certos conceitos, especialmente no tocante às relações de contato entre as diversas unidades geológicas citadas e seu posicionamento estratigráfico.

Um destes problemas refere-se às relações de contato entre os Grupos Canastra e Ibiá. Na base desta unidade e no contato com as rochas do Grupo Canastra, a norte de Coromandel, Barbosa et al. (1970) encontraram um metaconglomerado com matriz filítica e arcabouço de seixos de granito, quartzito e gnaisse, que os levou a posicionarem a Formação Ibiá acima do Grupo Canastra. Por outro lado, a ausência de metaconglomerados na base da Formação Ibiá na região de Araxá é notada por Simões e Navarro (1996). Estes autores afirmam que "na área estudada a Formação Ibiá faz contato tanto com a unidade supe- rior (quartzítica) quanto com a inferior do Grupo Canastra", sugerindo que se o contato é normal (com base em Pereira et al. 1992), provavelmente deva representar uma discordância angular. Alternativamente, pode indicar um "contato tectônico", exatamente como ficou demonstrado a partir dos dados de Seer (1999), que verificou ser a relação de contato entre o Grupo Ibiá e os Grupos Araxá e Canastra através de zonas de cisalhamento.

Um outro aspecto problemático refere-se às relações entre os grupos Araxá e Ibiá. Para Paulsen et al. (1974) e Ferrari (1989) existe transição entre as unidades Araxá e Ibiá. O último autor defende uma origem vulcânica para os metassedimentos Ibiá com base na abundância de plagioclásio e presença de clorita.

Por fim, questões básicas como o próprio significado do Grupo Araxá e sua cartografia podem ser consideradas. Assim, Besang et al.(1977) chamam a atenção para a existência de granitos nas proximidades de Araxá-Ibiá que não representam um embasamento mais antigo como supunham Barbosa et al. (1970). Estes problemas foram avaliados em detalhe por Seer (1999) que concluiu que os granitos são intrusivos apenas nas rochas do Grupo Araxá e têm assinatura geoquímica colisional. Adicionalmente, Braun e Baptista (1978) destacam o fato de que a "formação Ibiá ocorre ainda em torno do anel quartzítico do maciço alcalino do Barreiro (Araxá) e em intercalações nos quartzitos da Serra de Pirapetinga" a sul da cidade de Araxá, o que denota modificação na cartografia de Barbosa et al. (1970). Este fato foi também confirmado por Simões e Navarro (1996) e Seer (1999).

Consideradas, portanto, as questões acima reportadas, o presente trabalho se traduz num esforço no sentido de solucionar os problemas, à luz de recentes avanços apoiados em mapeamento geológico de detalhe, análise estrutural geométrica e cinemática, petrografia, geoquímica de rocha total e geocronologia.

1 - Caixa Postal 208, CEP 38183-070, Araxá, MG, e-mail: seer.aax@terra.com.br

2 - Instituto de Geociências, Universidade de Brasília, Campus Asa Norte, CEP 70910-900, Brasília, DF

3 - Departamento de Geologia, Universidade Federal de Ouro Preto, CEP 35400-000, Ouro Preto, MG

4- Centro Federal de Educação Tecnológica - Uned/Araxá, Av. Amazonas, 807, CEP 38180-000, Araxá, MG 

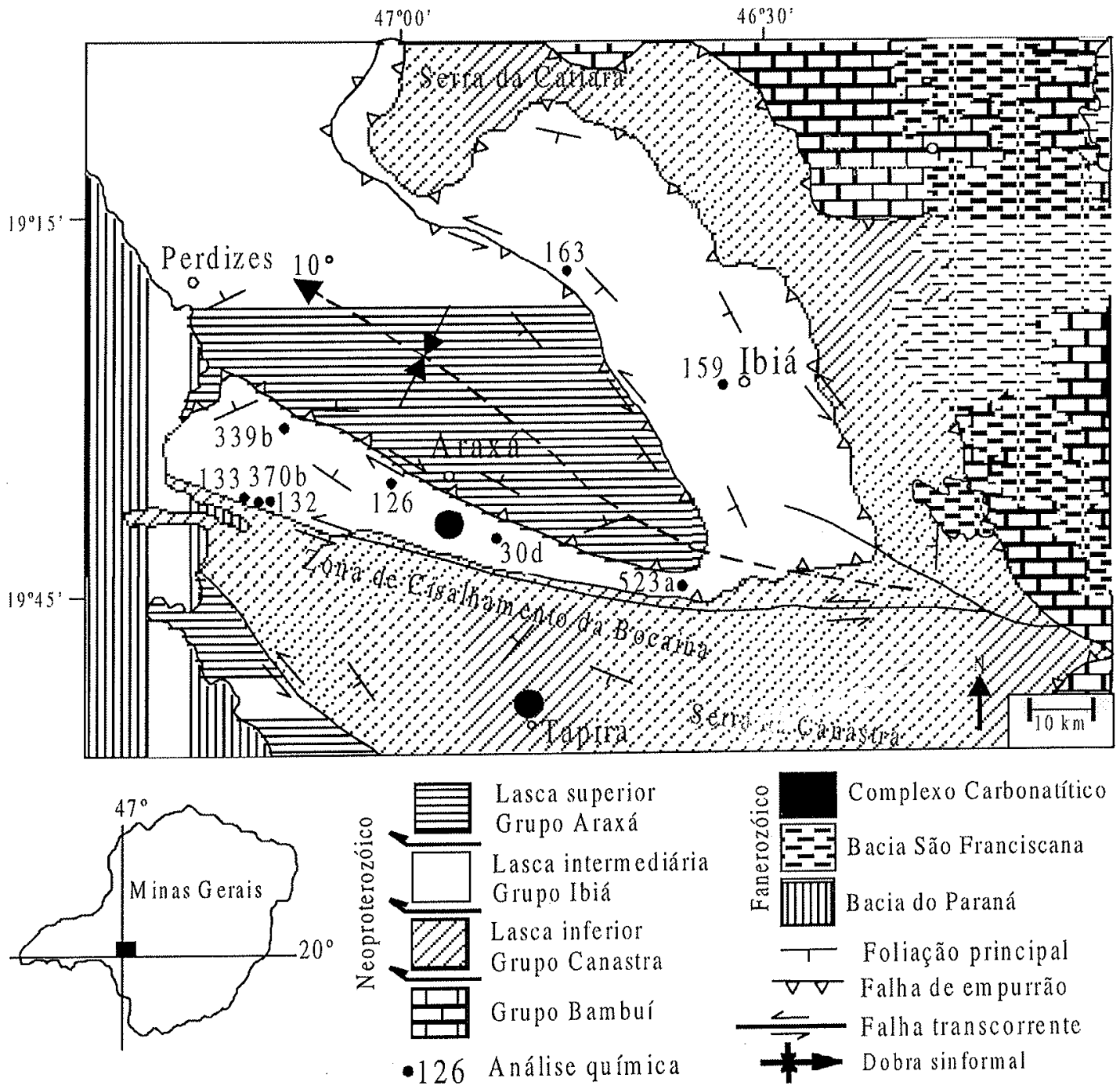

Figura I-Mapa geológico da sinforma de Araxá ( Seer 1999 - cartografia modificada de Barbosa et al. 1970).

\section{TECTONOESTRATIGRAFIA}

A região de Araxá está estruturada em uma dobra sinformal regional denominada Sinforma de Araxá (Simões e Navarro 1996), cuja linha de charneira apresenta direção aproximada $\mathrm{N} 70^{\circ} \mathrm{W}$ com caimento suave para NW (Fig. 1). Um sistema de falhas transcorrentes sinistrais, denominado localmente como Zona de Cisalhamento da Bocaina (Simões e Navarro 1997), trunca a estrutura sinformal em seu flanco sul e representa a continuidade de um sistema de falhas regional denominado Campos Altos Lagoa da Prata (Magalhães 1989).

A tectonoestratigrafia da região, estabelecida por Seer (1999), compreende três lascas tectônicas alóctones separadas por zonas de cisalhamento que configuram falhas de empurrão (Fig. 2).

Na lasca inferior, ocorrem os rochas do Grupo Canastra (conjunto de metassedimentos detríticos, em grande parte carbonosos e com fácies carbonatadas subordinadas). Esta, por sua vez, cavalga o Grupo Bambuí, uma cobertura autóctone do Cráton do São Francisco, situada a leste. A lasca tectônica intermediária reúne as rochas do Grupo Ibiá. Empurrada sobre esta ocorre a lasca tectônica superior que engloba as rochas do Grupo Araxá (conjunto dominantemente metaígneo máficoultramáfico - subordinadamente metassedimentar, intrudido por corpos de granitóides ricos em pegmatitos).

O Grupo Ibiá compreende um conjunto de metassedimentos detríticos metamorfisados em fácies xisto verde baixo, que se distribui a sul, leste e norte da cidade de Araxá. Seus litotipos principais são calcifilito, quartzo-filito, filito e quartzito micáceo com foliação bem desenvolvida. Foliações S-C são abundantes. É comum a presença de veios de quartzo e carbonato paralelos à foliação principal, com espes- suras centimétricas e mais raramente decimétricas. Estes veios achamse dobrados e rompidos. Com exceção do quartzito, as demais rochas apresentam coloração verde a verde acinzentado quando frescas, e rosadas quando intemperizadas. $O$ calcifilito e o quartzo-filito apresentam maior distribuição espacial e diferenciam-se apenas pela presença de carbonato nos primeiros. Seu aspecto em afloramento e amostras de mão é sempre o mesmo. Invariavelmente estão arranjados como ritmitos, cujas lâminas têm espessuras milimétricas a centimétricas (Fig. 3). Os ritmitos gradam para filitos verde-acinzentados e para quartzitos finos micáceos em direção ao topo estratigráfico.

Ao microscópio petrográfico, o bandamento do calcifilito e quartzo-filito é dado por variações composicionais ora predominando quartzo, feldspato, carbonato e mica branca nas bandas mais claras, ora clorita nas bandas mais escuras, sendo os demais minerais subordinados. Estas rochas são compostas de quartzo, feldspato potássico, plagioclásio, albita, clorita, mica branca, epidoto, carbonato, minerais opacos e raros grãos de turmalina, zircão e granada. O tamanho dos grãos é quase sempre submilimétrico, em geral entre 0,1 a $0,3 \mathrm{~mm}$ e pode variar de banda para banda, e mesmo dentro de uma banda. Em geral, as bandas são descontînuas lateralmente. Os feldspatos são, principalmente, plagioclásio e, subordinadamente, ortoclásio. No entanto, algumas seções delgadas exibem quantidades maiores deste último. O plagioclásio pode constituir clastos imersos em matriz fina, ou então aparece junto aos agregados de quartzo e carbonato, quando também ocorre como grãos de tamanhos similares a estes. Feldspato potássico, distribuído ao longo de alguns horizontes associados com grãos quebrados e arredondados de turmalina, granada e zircão, circundados 


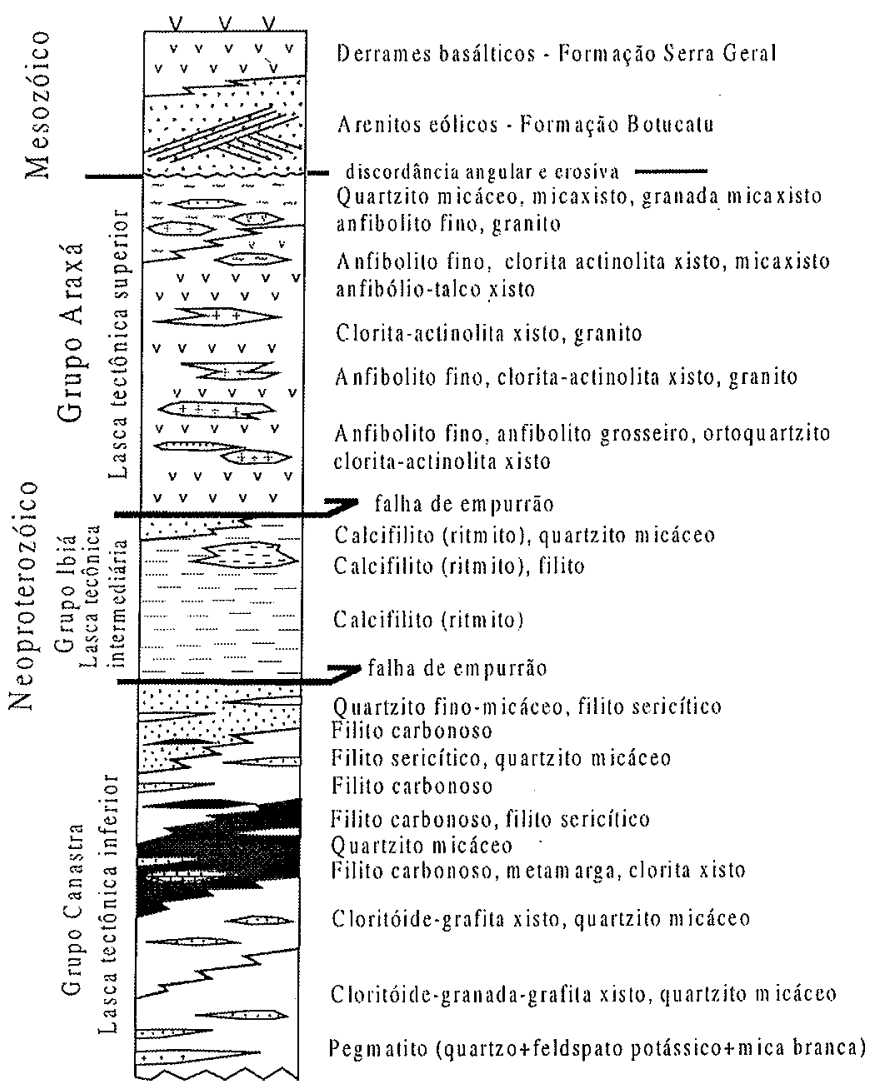

Figura 2 - Tectonoestratigrafia da Sinforma de Araxa (Seer 1999).

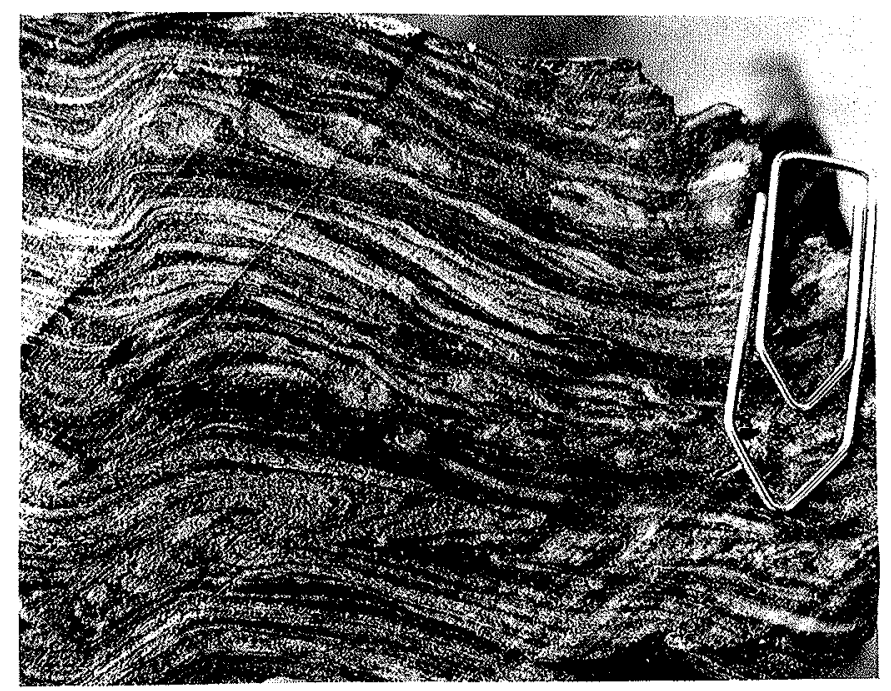

Figura 3 - Aspecto dos calcifilitos em amostra de mão. Notar o bandamento rímico marcado por lâminas milimétricas de metassiltitos-quartzitos muito finos (claras) intercaladas a lâminas de filito (escuras).

pela foliação, indicam sua origem detrítica. Do mesmo modo ocorrem alguns grãos de quartzo, com faces retas e bordos parcialmente corroídos lembrando quartzo de rochas vulcânicas.

Esta mineralogia reflete a composição das áreas fonte, já que foram detectadas bandas com grãos detríticos. Deste modo, o bandamento composicional reflete o acamamento sedimentar original, marcado por intercalações de siltitos e arenitos finos a muito finos com argilitos. Lembram laminações plano-paralelas de ritmitos. A presença de plagioclásio e ortoclásio nestes sedimentos restringe as condições de
Tabela I - Resultados analíticos para os rochas metassedimentares do Grupo Ibiá. Elementos maiores em \% e traços em $\mathrm{ppm}$.

\begin{tabular}{|c|c|c|c|c|c|c|c|c|c|}
\hline Amostra & $30 \mathrm{~d}$ & $370 \mathrm{~b}$ & $339 \mathrm{~b}$ & 133 & 132 & $523 a$ & 163 & 126 & 159 \\
\hline $\mathrm{SiO}_{2}$ & 59,31 & 60,9 & 63,15 & 63,3 & 64,77 & 64,83 & 65,97 & 65,98 & 67,81 \\
\hline $\mathrm{TiO}_{2}$ & 0,88 & 0,82 & 0,96 & 0,81 & 0,79 & 0,78 & 0,98 & 1,03 & 0,95 \\
\hline $\mathrm{Al}_{2} \mathrm{O}_{3}$ & 15,64 & 13,67 & 12,46 & 12,83 & 11,87 & 12,48 & 12,84 & 12,71 & 12,81 \\
\hline $\mathrm{Fe}_{2} \mathrm{O}_{3}$ & 2,77 & 2,17 & 1,74 & 1,86 & 2,33 & 2,57 & 4,01 & 1,84 & 1,76 \\
\hline $\mathrm{FeO}$ & 5,49 & 4,5 & 4,11 & 3,97 & 4,02 & 3,39 & 2,82 & 4,34 & 4,2 \\
\hline $\mathrm{FeO}_{\mathrm{T}}$ & 7,98 & 6,45 & 5,68 & 5,64 & 6,8 & 5,7 & 6,43 & 6 & 5,78 \\
\hline $\mathrm{Fe}_{2} \mathrm{O}_{3} \mathrm{~T}$ & 8,87 & 7,17 & 6,31 & 6,27 & 6,8 & 6,34 & 7,14 & 6,66 & 6,43 \\
\hline $\mathrm{MnO}$ & 0,1 & 0,17 & 0,17 & 0,15 & 0,16 & 0,13 & 0,06 & 0,36 & 0,09 \\
\hline $\mathrm{MgO}$ & 3,86 & 3,27 & 2,74 & 2,82 & 2,78 & 2,73 & 2,57 & 3,17 & 2,48 \\
\hline $\mathrm{CaO}$ & 0,18 & 2,66 & 3,69 & 2,95 & 2,54 & 2,28 & 0,5 & 0,99 & 0,89 \\
\hline $\mathrm{Na}_{2} \mathrm{O}$ & 2,18 & 2,72 & 3,91 & 2,97 & 2,73 & 3,15 & 2,49 & 2,93 & 3,7 \\
\hline $\mathrm{K}_{2} \mathrm{O}$ & 3,03 & 2,69 & 1,56 & 2,22 & 2,09 & 1,87 & 2,9 & 1,98 & 1,75 \\
\hline $\mathrm{P}_{2} \mathrm{O}_{5}$ & 0,13 & 0,14 & 0,12 & 0,17 & 0,16 & 0,12 & 0,11 & 0,13 & 0,16 \\
\hline LOI & 4,72 & 5,74 & 5,26 & 5,03 & 5,06 & 4,47 & 2,84 & 3,35 & 2,9 \\
\hline Total & 98,29 & 99,45 & 99,87 & 99,08 & 99,3 & 98,8 & 98,09 & 98,81 & 99,3 \\
\hline $\mathrm{Ba}$ & 166 & 566 & 203 & 665 & 555 & 253 & 566 & 154 & 104 \\
\hline Sr & 56 & 177 & 258 & 161 & 152 & 138 & 41 & 105 & 86 \\
\hline Y & 15 & 45 & 31 & 40 & 171 & 49 & 27 & 51 & 34 \\
\hline $\mathrm{Zr}$ & 202 & 163 & 94 & 146 & 125 & 178 & 156 & 138 & 183 \\
\hline $\mathrm{Nb}$ & 8 & 13 & 13 & 14 & 13 & 10 & 16 & 14 & 14 \\
\hline $\mathrm{Zn}$ & 147 & 144 & 99 & 114 & 142 & 96 & 85 & 118 & 118 \\
\hline $\mathrm{Cu}$ & 39 & 44 & 27 & 26 & 36 & 28 & 19 & 31 & 30 \\
\hline $\mathrm{Ni}$ & 57 & 80 & 62 & 68 & 76 & 42 & 23 & 65 & 56 \\
\hline V & 85 & 100 & 94 & 100 & 100 & 99 & 98 & 106 & 93 \\
\hline $\mathrm{Cr}$ & 85 & 95 & 104 & 95 & 81 & 59 & 61 & 140 & 99 \\
\hline Co & 65 & 71 & 90 & 58 & 88 & 91 & 62 & 100 & 71 \\
\hline $\mathrm{Be}$ & 3 & 3 & 2 & 3 & 2 & 2 & 3 & 2 & 2 \\
\hline $\mathrm{La}$ & 7,61 & nd & 16,84 & 16,6 & 23,67 & 57 & nd & 53,2 & nd \\
\hline $\mathrm{Ce}$ & 40,14 & nd & 42,52 & 40,82 & 42,73 & 44,92 & nd & 47,09 & nd \\
\hline $\mathrm{Nd}$ & 12,64 & nd & 25,64 & 24,23 & 27,24 & 5,92 & nd & 5,94 & nd \\
\hline $\mathrm{Sm}$ & 3,36 & nd & 4,98 & 4,37 & 5,14 & 9,11 & nd & 8,53 & nd \\
\hline EII & 0,89 & nd & 1,34 & 1,25 & 1,33 & 2,73 & nd & 2,34 & nd \\
\hline $\mathrm{Gd}$ & 7,08 & nd & 5,82 & 6,55 & 7,19 & 10,36 & nd & 8,48 & nd \\
\hline Dy & 3,65 & nd & 4,81 & 5,28 & 8,86 & 9,43 & nd & 7,7 & nd \\
\hline Ho & 1,29 & nd & 1,64 & 1,8 & 3,24 & 2,38 & nd & 2,28 & nd \\
\hline Er & 3,16 & nd & 4,17 & 4,17 & 10,03 & 5,6 & nd & 5,76 & nd \\
\hline $\mathrm{Yb}$ & 1,99 & nd & 1,93 & 2,42 & 6,09 & 3,15 & nd & 3,72 & nd \\
\hline Lu & 1,12 & nd & 0,56 & 0,89 & 1,42 & 0,77 & nd & 0,92 & nd \\
\hline
\end{tabular}

sua sedimentação. Segundo Tucker (1985), a maioria dos feldspatos em sedimentos é de primeira geração e sua presença é controlada pela taxa de erosão (que deve ser alta) e pelo clima (que deve ter intemperismo dominantemente físico). No entanto, erosão rápida em uma área em soerguimento poderá produzir feldspatos, a despeito de um clima úmido. Mas um clima árido facilitará a presença de maior volume de feldspatos frescos nos sedimentos. Os carbonatos também são abundantes nestas rochas, tanto que recebem a denominação de calcifilito (Barbosa et al. 1970, Pereira 1992), podendo-se atribuir sua origem tanto a processos sedimentares e/ou diagenéticos quanto a reações metamórficas de quebra do plagioclásio e sua transformação para termos mais sódicos, sob a influência de um fluido rico em $\mathrm{CO}_{2}$. O principal efeito destas reações e da pressão dos fluidos foi a geração de veios de quartzo e carbonato. O Grupo Ibiá é a unidade geológica de mais baixo metamorfismo na sinforma de Araxá, alcançando, no máximo, a zona da clorita da fácies xisto verde. As unidades Canastra e Araxá alcançaram, pelo menos, a zona da granada da fácies xisto verde, porém determinações da composição de anfibólio e plagioclásio demonstram que as rochas metamáficas do Grupo Araxá alcançaram a fácies anfibolito (Seer 1999). Como a unidade Ibiá está posicionada entre duas unidades com metamorfismo mais elevado, delas separada por zonas de cisalhamento, supõe-se que, durante o evento metamórfico principal, ela estava em posição crustal mais rasa e, portanto, espacialmente afastada daquelas, uma vez que não foram encontradas transições nas paragêneses metamórficas.

GEOQUÍMICA DE ROCHA TOTAL Normalmente, a composição e a textura dos grãos detríticos e as estruturas sedimentares presentes em sedimentos clásticos terrígenos são suficientes para suportar interpretações a respeito do ambiente de sedimentação e da área-fonte dos sedimentos. A destruição de feições sedimentares primárias, durante deformação e metamorfismo afeta as interpretações quanto aos paleoambientes de sedimentação. As dificuldades aumentam em rochas de granulometria fina, como o siltito e argilito, necessitando-se de técnicas laboratoriais complementares (Tucker 1985). Segundo Bhatia (1983) a composição química de rochas sedimentares terrígenas é função de complexa interação entre o relevo e a composição da área-fonte, 
Tabela 2 - Comparação dos valores médios de elementos maiores das rochas metassdimentares do Grupo lbiá com médias de outras rochas detríticas. (*) folhelhos fanerozóicos, ardósias I pré-cambrianas, ardósias 2 paleozóicas (Pettijohn, 1975); (**) Tucker (I985); (***) grauvacas paleozóicas (Fuchtbauer 1974); $n d=$ não determinado.

\begin{tabular}{|c|ccccccccccc|}
\hline Litologial\% & $\mathrm{SiO}_{2}$ & $\mathrm{TiO}_{2}$ & $\mathrm{Al}_{2} \mathrm{O}_{3}$ & $\mathrm{Fe}_{2} \mathrm{O}_{3}$ & $\mathrm{FeO}$ & $\mathrm{MgO}$ & $\mathrm{CaO}$ & $\mathrm{Na}_{2} \mathrm{O}$ & $\mathrm{K}_{2} \mathrm{O}$ & $\mathrm{P}_{2} \mathrm{O}_{5}$ & $\mathrm{MnO}$ \\
\hline Ibiá & 64 & 0,88 & 13,03 & 2,33 & 4,09 & 2,93 & 1,83 & 2,97 & 2,23 & 0,13 & 0,15 \\
Grauvacas** & 68,85 & 0,6 & 13,5 & 1,6 & 3,5 & 2,1 & 2,5 & 2,9 & 2 & nd & nd \\
Grauvacas*** & 68,85 & 0,74 & 12,05 & 2,72 & 2,03 & 2,96 & 0,5 & 4,87 & 1,81 & 0,06 & 0,05 \\
Folhelhos* & 58,1 & 0,65 & 15,4 & 4,02 & 2,45 & 2,44 & 3,11 & 1,3 & 3,24 & 0,17 & nd \\
Ardósias1* & 56,3 & 0,77 & 17,24 & 3,83 & 5,09 & 2,54 & 1 & 1,23 & 3,79 & 0,14 & 0,1 \\
Ardósias2* & 60,61 & 0,73 & 17,32 & 2,25 & 2,66 & 2,6 & 1,54 & 1,19 & 3,69 & nd & nd \\
\hline
\end{tabular}

intemperismo, transporte e diagênese, mas com o ambiente geotectônico representando o controle primário dos processos. O mesmo autor destaca que nem sempre a composição dos clastos reflete diretamente o ambiente crustal de origem dos sedimentos, pelo fato de que fragmentos de rochas vulcânicas e plutônicas podem ter se originado a partir de arcos magmáticos desenvolvidos em diversos ambientes geotectônicos. Os estudos de Bhatia (1983), Bhatia e Crook (1986), Floyd et al. (1991) e Cox e Lowe (1995) propuseram um conjunto de critérios geoquímicos para discriminar os ambientes geotectônicos de origem de rochas sedimentares e metassedimentares. A presente abordagem é baseada nas conclusōes destes trabalhos. Os critérios seguidos para a seleção das amostras de rochas metassedimentares do Grupo Ibiá basearam-se na ausência de efeitos intempéricos, homogeneidade textural, ausência de veios e fraturas preenchidas por minerais secundários e representatividade geológica. As amostras foram preparadas e analisadas para elementos maiores e traços no Laboratório de Geoquímica da Universidade de Brasília. Os óxidos e elementos $\mathrm{SiO}_{2}$, $\mathrm{TiO}, \mathrm{Al}_{2} \mathrm{O}_{3}, \mathrm{Fe}_{2} \mathrm{O}_{3}, \mathrm{MnO}, \mathrm{CaO}, \mathrm{P}, \mathrm{O}_{5}, \mathrm{Zn}, \mathrm{Co}, \mathrm{Ni}, \mathrm{Cr}, \mathrm{V}, \mathrm{Be}, \mathrm{Cu}, \mathrm{Zr}$, $\mathrm{Y}, \mathrm{S}^{2}$ e $\mathrm{Ba}$, foram analisados por ICP/PLASMA, o FeO por volumetria, $\mathrm{Na}_{2} \mathrm{O}$ e $\mathrm{K}_{2} \mathrm{O}$ através de absorção atômica e a perda-ao-fogo por gravimetria. Os Elementos Terras Raras (ETR) foram separados através do método de minicolunas conectadas à uma bomba peristáltica de 6 canais, da marca ALITEA C6-XV, e analisados em equipamento ICP/AES. As amostras analisadas correspondem a calcifilito e sua localização está registrada na figura 1 .

Elementos maiores Os resultados analíticos para os calcifilitos do Grupo Ibiá são reproduzidos na Tabela 1. A comparação entre os valores de elementos maiores de diversos tipos de rochas sedimentares e os metassedimentos do Grupo Ibiá permite traçar um paralelo com as grauvacas, especialmente quanto aos teores de $\mathrm{Al}_{2} \mathrm{O}_{3}$. Diferenciam-se dos folhelhos fanerozóicos e das ardósias pré-cambrianas e fanerozóicas que apresentam teores mais elevados de $\mathrm{Al}_{2} \mathrm{O}_{3}$ e $\mathrm{K}_{2} \mathrm{O}$, e dos arenitos arcoseanos, que têm mais $\mathrm{SiO}_{2}$ e $\mathrm{K}_{2} \mathrm{O}$ e menos $\mathrm{Al}_{2} \mathrm{O}_{3}$. Os altos teores de $\mathrm{MgO}$ e $\mathrm{FeO}$ devem-se à presença de matriz clórítica $\mathrm{e}$ os valores de $\mathrm{Na}_{2} \mathrm{O}$, ao plagioclásio ou, em parte, fixação de água do mar em sedimentos argilosos (Tabela 2).

A semelhança composicional com grauvacas é interessante. As grauvacas possuem matriz finamente granulada, composta de clorita, sericita e grãos de quartzo e feldspato. No arcabouço contêm quartzo, feldspato e fragmentos de rochas vulcânicas. Estes sedimentos muitas vezes são sinorogênicos e acham-se associados a margens continentais ativas e a arcos-de-ilhas vulcânicos (Tucker 1985). As variações químicas dos metassedimentos do Grupo Ibiá podem ser melhor apreciadas através dos diagramas de Harker (Fig. 4).

Nestes diagramas, para efeitos comparativos, foram plotadas as variações químicas dos sedimentos terrígenos das suites Tamworth (Devoniano), Hill End (Siluriano-Devoniano), Hodgkinson (Devoniano), Bendigo (Ordoviciano) e Cookman (Siluriano), que representam grauvacas finas provenientes de ambientes tectônicos bem estudados e estabelecidos do leste da Austrália (Bhatia 1983). As linhas de evolução dos gráficos representam a variação composicional de sedimentos gerados em arcos-de-ilhas intraoceânicos (AIO) (A), com baixa maturidade, até sedimentos de margens passivas (MP) (B), com elevada maturidade composicional, passando por arcos-de-ilhas continentais (AIC) e margens continentais ativas (MCA). Bhatia (1983) refere-se aos arcos-de-ilhas continentais como arcos-de-ilhas formados sobre uma crosta continental bem desenvolvida (Bacia de Lau, Mar do Japão) e utiliza o termo margem continental ativa para
Tabela 3. Resultados de análises químicas para elementos traço (em ppm) das rochas metassedimentares do Grupo Ibiá (I) em comparação com dados químicos para rochas sedimentares de AIO (2 e3), AIC (4), MCA (5), AIC+MCA (6), MP (7 e 8) e OIP (9). (*) Dados de Bhatia e Crook (1986), (**) dados de Floyd et al. (1991).

\begin{tabular}{|c|ccccccccc|}
\hline & 1 & $2^{*}$ & $3^{* *}$ & $4^{*}$ & $5^{*}$ & $6^{* *}$ & $7^{*}$ & $8^{* *}$ & $9^{* *}$ \\
\hline $\mathrm{Ba}$ & 359 & 370 & 370 & 444 & 522 & 481 & 253 & 255 & 209 \\
$\mathrm{Sr}$ & 130 & 637 & 362 & 250 & 141 & 274 & 66 & 72 & 432 \\
$\mathrm{Zr}$ & 153 & 96 & 99 & 229 & 179 & 146 & 298 & 302 & 146 \\
$\mathrm{Nb}$ & 12,7 & 2 & 5 & 8,5 & 10,7 & 9 & 7,9 & 7 & 27 \\
$\mathrm{Y}$ & 51,4 & 19,5 & 15 & 24,2 & 24,9 & 17 & 27,3 & 24 & 20 \\
$\mathrm{La}$ & 29,15 & 8,72 & 10 & 24,4 & 33 & 23 & 33,5 & 22 & 10 \\
$\mathrm{Ce}$ & 43 & 22,53 & 22 & 50,5 & 72,7 & 48 & 71,9 & 56 & 24 \\
$\mathrm{Nd}$ & 16,93 & 11,36 & 10 & 20,8 & 25,4 & 24 & 29 & 39 & 15 \\
$\mathrm{~V}$ & 105 & 131 & 188 & 89 & 48 & 106 & 31 & 44 & 400 \\
$\mathrm{Cr}$ & 91 & 37 & 49 & 51 & 26 & 55 & 39 & 29 & 230 \\
$\mathrm{Co}$ & 77,3 & 18 & $\mathrm{nd}$ & 12 & 10 & $\mathrm{nd}$ & 5 & $\mathrm{nd}$ & $\mathrm{nd}$ \\
$\mathrm{Ni}$ & 61 & 11 & 22 & 13 & 10 & 31 & 8 & 15 & 114 \\
$\mathrm{Cu}$ & 31,1 & 23 & 29 & 11 & 8 & 22 & 6 & 8 & 77 \\
$\mathrm{Zn}$ & 118 & 89 & 88 & 74 & 52 & 73 & 26 & 49 & 122 \\
\hline
\end{tabular}

margens do tipo Andina. Os detritos sedimentares de bacias situadas nas proximidades de AIC são derivados principalmente de rochas vulcânicas félsicas. Como o termo AIC é polêmico, no presente trabalho é utilizado o termo AIM (arco-de-ilhas maduro) no sentido usado por Kearey e Vine (1996), aplicado para os arcos da Bacia de Lau e do Japão.

As rochas metassedimentares do Grupo Ibiá situam-se entre os valores das suites Tamworth e Hill End, que representam ambientes de AIO e AIM, respectivamente.

Segundo Bhatia (1983), com relação aos elementos maiores, os melhores discriminantes de ambientes geotectônicos são os diagramas $\mathrm{TiO}_{2}, \mathrm{Al}_{2} \mathrm{O}_{3} / \mathrm{SiO}_{2}, \mathrm{~K}_{2} \mathrm{O} / \mathrm{Na}_{2} \mathrm{O}, \mathrm{e} \mathrm{Al}_{2} \mathrm{O}_{3} /\left(\mathrm{CaO}+\mathrm{Na}_{2} \mathrm{O}\right)$ versus $\mathrm{Fe}_{2} \mathrm{O}_{31}+$ $\mathrm{MgO}$, onde $\mathrm{Fe}_{2} \mathrm{O}_{3}$ representa ferro total. Plotando-se os dados dos metassedimentos do Grupo Ibiá nestes diagramas, verifica-se que os valores caem no campo dos $\mathrm{AIO}\left(\mathrm{TiO}_{2}\right)$ com alguma tendência para $\operatorname{AIM}\left(\mathrm{Al}_{3} \mathrm{O}_{3} / \mathrm{SiO}_{2}\right)$ (Fig. 5).

Nos diagramas $\mathrm{K}_{2} \mathrm{O} / \mathrm{Na}_{2} \mathrm{O} \times \mathrm{Fe}_{2} \mathrm{O}_{31}+\mathrm{MgO}$ e $\mathrm{Al}_{2} \mathrm{O}_{3} /\left(\mathrm{CaO}+\mathrm{Na}_{2} \mathrm{O}\right)$ os pontos dos metassedímentos do Grupo Ibiá caem fora dos campos das suites australianas. Isto se deve aos teores relativamente mais baixos de $\mathrm{Na}, \mathrm{O}$ e mais elevados de $\mathrm{K}_{2} \mathrm{O}$ nos primeiros, em relação aos últimos, o que eleva as razões $\mathrm{K}_{2} \mathrm{O} / \mathrm{Na}_{2} \mathrm{O}$. No diagrama $\mathrm{Al}_{2} \mathrm{O}_{3} /\left(\mathrm{CaO}+\mathrm{Na}_{2} \mathrm{O}\right) 0$ efeito do $\mathrm{Na}_{2} \mathrm{O}$ é reduzido e alguns pontos caem dentro do campo OIA. Este fato pode ser explicado pela presença de grãos detríticos de feldspatos potássicos que, aliados à grãos de turmalina, granada e zircão, indicam áreas fonte graníticas, ricas em $\mathrm{K}_{2} \mathrm{O}$, para os metassedimentos do Grupo Ibiá. Pode ser também explicado por lixiviação de $\mathrm{Na}_{2} \mathrm{O}$. Neste último caso, a probabilidade de ocorrer lixiviação de outros elementos considerados móveis em ambientes superficiais ou metamórficos seria a mesma e eles deveriam mostrar variações maiores dentro da população analisada, o que não ocorre. Segundo Cox e Lowe (1995) a estabilidade composicional dos elementos maiores e traços de argilitos persiste tanto durante processos diagenéticos como durante metamorfismo.

Deste modo, levando-se em conta que a composição química dos metassedimentos é herdada das áreas-fontes, pode-se dizer que é notável o distanciamento composicional dos metassedimentos do Grupo 

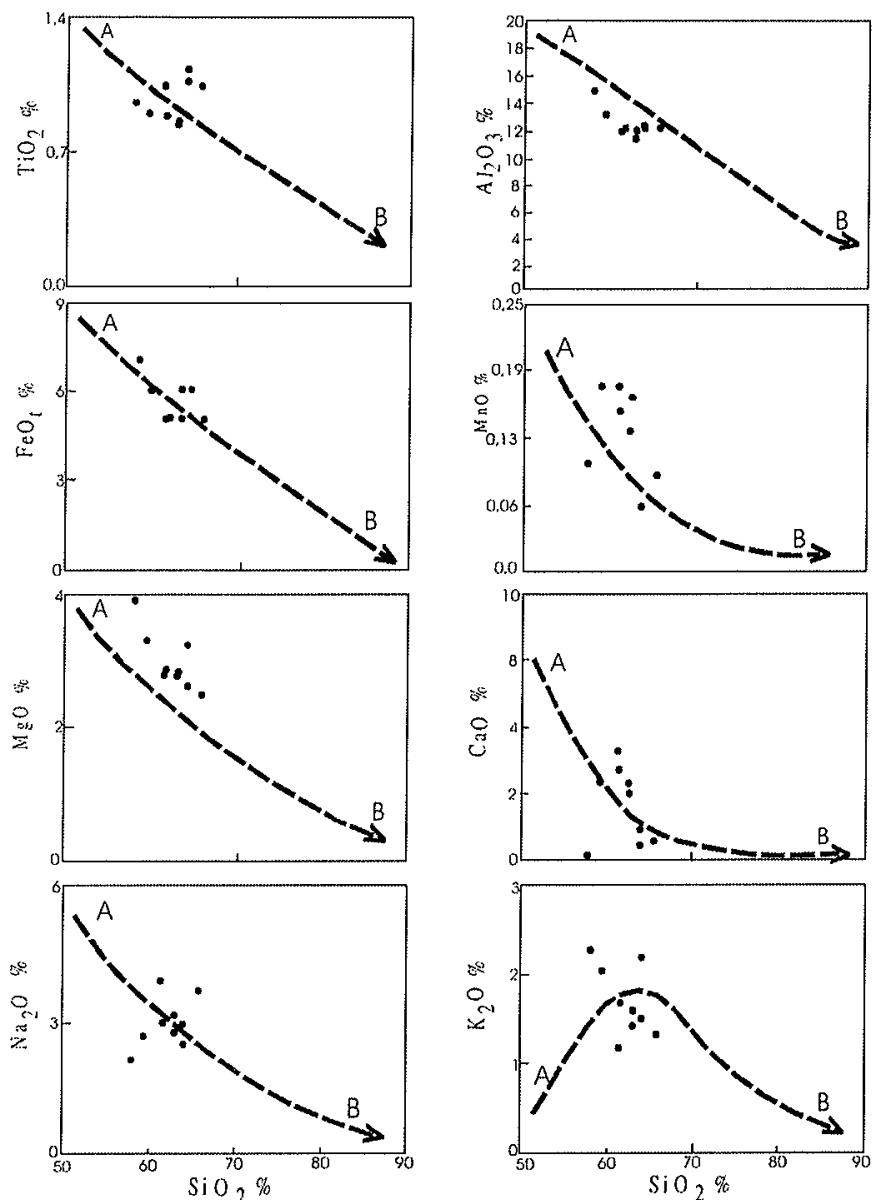

Figura 4-Diagramas de variaçäo de Harker para os elementos maiores dos metassedimentos do Grupo Ibiá. Linhas tracejadas indicam variações composicionais típicas para grauvacas originadas em arcos-de-ilhas intraoceânicos $(A)$ até margens passivas $(B)$, passando por anbientes intermediarios de arcos-de-ilhas continentais e margens continentais ativas (Bhatia, 1983).

a)

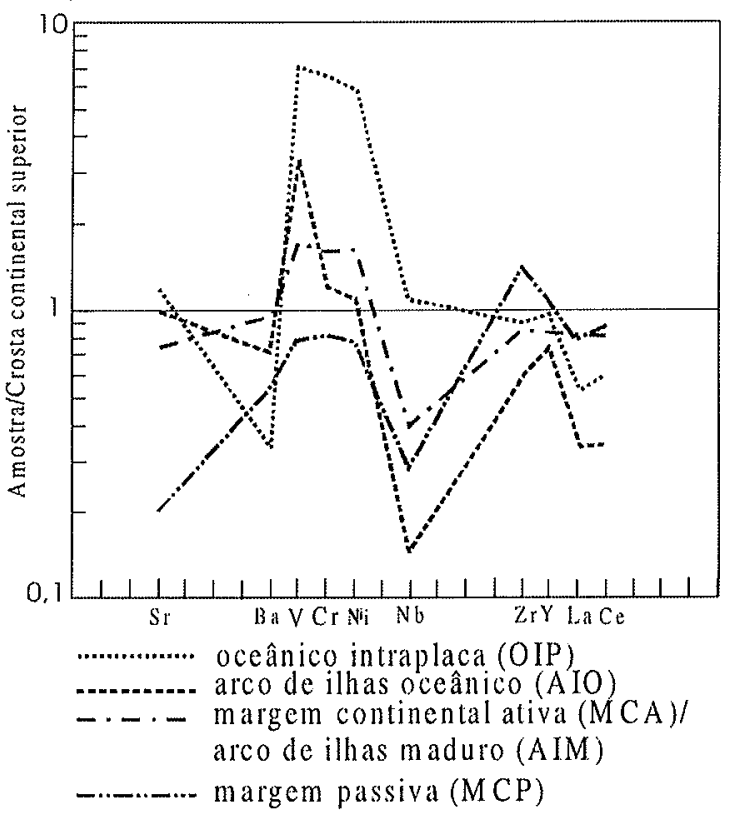

Ibiá com os campos de ambientes de MP e relevante sua semelhança com ambientes de AIO. Esta questão é importante uma vez que limita as possíveis áreas-fonte destes metassedimentos, que não poderiam estar localizadas, por exemplo, à margem do continente paleoproterozóico do São Francisco, situado a leste da região de Araxá.

Elementos traço Bhatia e Crook (1986) e Floyd et al. (1991) propõem alguns parâmetros com relação aos elementos traço que auxiliam na discriminação das áreas-fontes dos sedimentos. Segundo
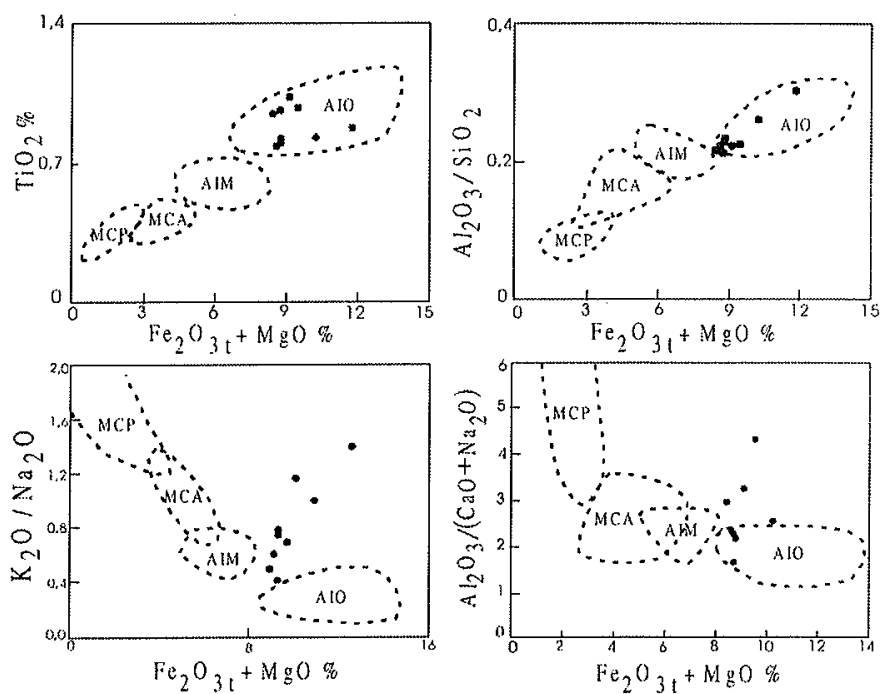

Figura 5-Diagramas discriminantes para ambientes geotectônicos. Os campos tracejados representam as variacöes composicionais de grauvacas de AIO - AIM, MCA e MP, com base em Bhatia (1983). Os pontos representam as amostras de rochas metassedimentares do Grupo Ibiá.

Tabela 4-Dados isotópicos Sm-Nd para três amostras de metassedimentos do Grupo Ibiá na Sinforma de Araxá.

\begin{tabular}{|cccccccc|}
\hline Amostra & lilologia & $\mathrm{Sm}(\mathrm{ppm})$ & $\mathrm{Nd}(\mathrm{ppm})$ & ${ }^{1+7} \mathrm{Sm} /{ }^{141} \mathrm{Nd}$ & ${ }^{1+3} \mathrm{Nd}^{14+4} \mathrm{Nd}$ & $\varepsilon_{\mathrm{Nd}}$ & $\mathrm{T}_{\mathrm{vM}}$ \\
\hline 133 & Calcifilito & 4,35 & 20,07 & 0,131 & 0,512319 & $-6,22$ & 1,33 \\
3706 & Calcifilito & 5,6561 & 26,326 & 0,1299 & $0,512322(18)$ & $-6,16$ & 1,3 \\
$523:$ & calcifilito & 12,036 & 62 & 0,174 & $0,512305(22)$ & $-6,49$ & 1,161 \\
\hline
\end{tabular}

b)

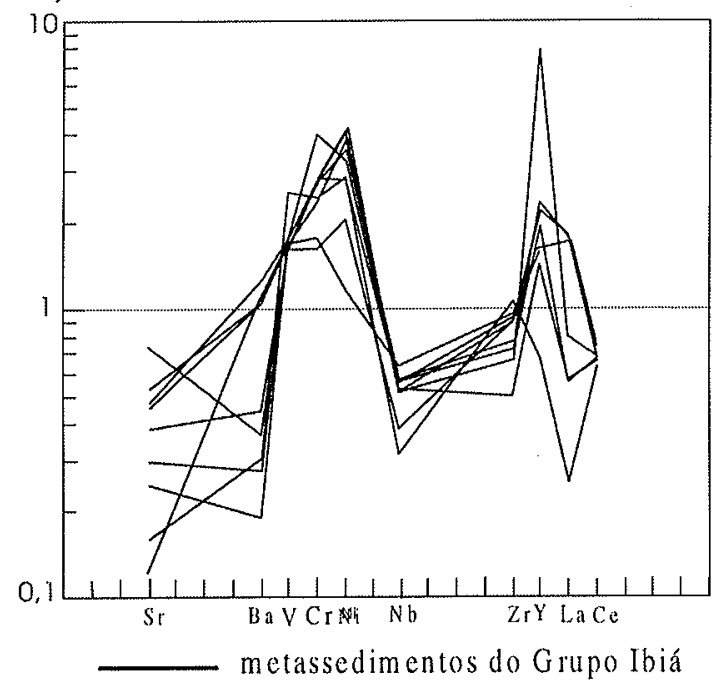

Figura 6 - Aracnideogramas para elementos traço de diversos ambientes tectônicos (dados de Floyd et al. 199J) em comparação com as curvas dos metassedimentos do Grupo Ibiá. 


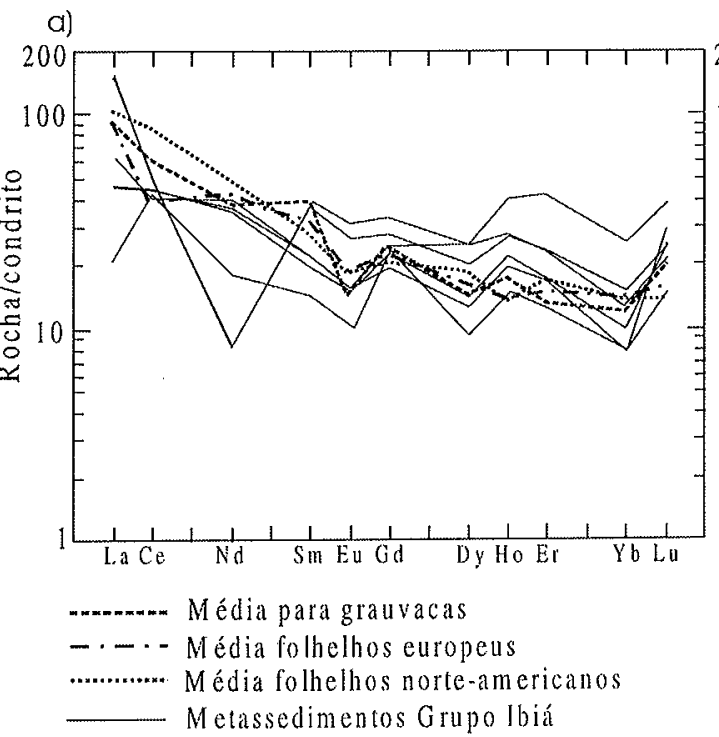

b)

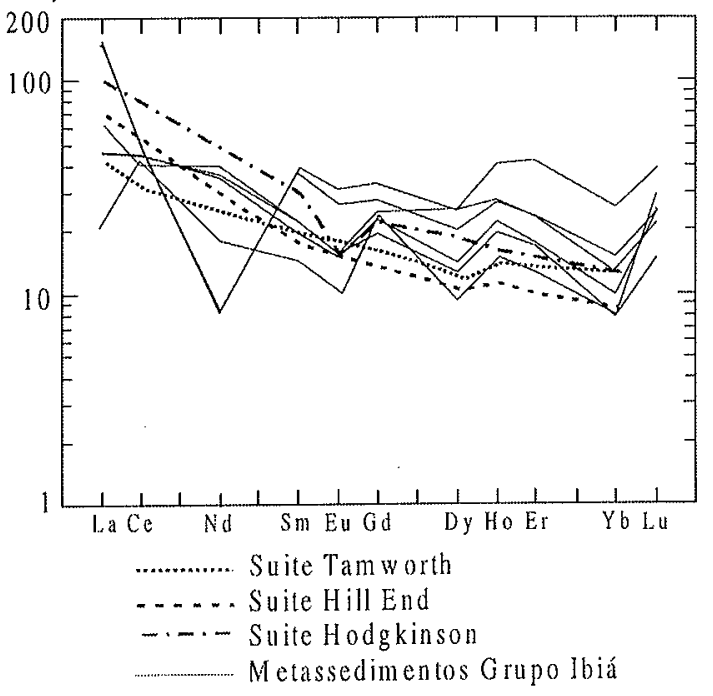

Figura 7 - a) Comparação dos padrões de distribuição dos ETR do Grupo Ibiá com médias de folhethos e grauvacas (Henderson, 1984). b) Conparação dos padróes de ETR do Grupo Ibiá com curvas estabelecidas para grauvacas de suites australianas (Bhatia e Crook 1986).

Bhatia e Crook (1986) a abundância de Al, Ti, Fe, Mg, e Na e dos elementos traço Sc, V, Co, $\mathrm{Zn}$ e Ga indica fontes vulcânicas. A abundância dos elementos $\mathrm{K}, \mathrm{Ba}, \mathrm{La}, \mathrm{Ce}, \mathrm{Nd}$, Th, U, Nb, $\mathrm{Zr}$, Rb e Pb acha-se relacionada à micas, feldspatos potássicos e minerais pesados (turmalina, zircão e rutilo), portanto a fontes graníticas ou detritos reciclados.

Floyd et al. (1991) mostram que o grau de seleção de um sedimento, a presença de minerais pesados e a entrada de detritos de origem máfica podem dificultar as análises baseadas em diagramas binários e ternários e nem sempre fornecer uma correlação direta entre composição e área fonte e, portanto, ambiência tectônica. Além disso, destacam o caráter geográfico limitado do trabalho de Bhatia (1983) e Bhatia e Crook (1986), embora estes autores tenham feito correlações entre as rochas sedimentares da Austrália com sedimentos modernos de diversos ambientes. Floyd et al. (1991) propõem um esquema mais abrangente, baseado em aracnídeogramas de elementos traço importantes que podem mostrar a participação de áreas fonte diferentes. Além disso, utilizam médias mundiais de análises químicas de rochas cujos ambientes tectônicos se encontram bem estabelecidos e comparam-nas utilizando normalização em relação à crosta continental superior. Comparando-se os dados químicos de elementos traço dos metassedimentos do Grupo Ibiá com dados de Bhatia e Crook (1986) e Floyd et al. (1991), pode-se traçar um paralelo entre os diversos ambientes tectônicos (Tab 3).

Os valores de $\mathrm{Ba}$ dos metassedimentos do Grupo Ibiá estão próximos de AIO. Sr e Nb aproximam-se dos valores para MCA. Zr, $\mathrm{La}, \mathrm{Ce}$ e V sugerem padrões similares aos de AIM e MCA. $\mathrm{Cr}, \mathrm{Co}, \mathrm{Ni}, \mathrm{Cu}$ e Zn são muito elevados e indicam forte contribuição de detritos máficos, enquanto os altos valores de $\mathrm{Y}$ mostram contribuição em minerais pesados, talvez monazita, indicando fontes de rochas ígneas félsicas.

Utilizando aracnídeogramas é possível comparar as tendências dos elementos traços dos metassedimentos do Grupo Ibiá com as tendências de sedimentos de diversos ambientes tectônicos (Fig. 6).

Dos diagramas deduz-se que a curva de melhor ajuste aos valores dos metassedimentos do Grupo Ibiá é a de AIM e MCA. A curva referente aos AIO é similar mas seus valores absolutos são diferentes. As anomalias positivas ( $>1)$ de $\mathrm{V}, \mathrm{Cr}$ e Ni, nas três curvas, indicam contribuição de detritos originários de rochas máficas. A curva dos sedimentos oceânicos intraplaca (OIP), apresenta forte anomalia positiva de $\mathrm{V}, \mathrm{Cr}$ e Ni, bem acima dos valores das curvas anteriores, indicando grande contribuição de detritos de origem máfica. Deve-se destacar que esta anomalia é expressiva nos metassedimentos do Grupo Ibiá em relação às anomalias para AIO e AIM. Anomalias negativas $(<1)$ de $\mathrm{Nb}$ são comuns a todos os sedimentos menos para os OIP. Nos metassedimentos do Grupo Ibiá esta anomalia assemelha-se à de AIM e MCA.
Com relação aos valores de La e Ce as tendências de todas as curvas são similares, mas para o Grupo Ibiá ocorrem tanto valores elevados (fontes félsicas) como baixos (fontes máficas) de La. Nos metassedimentos do Grupo Ibiá ocorre forte anomalia positiva de $\mathrm{Y}$, $\mathrm{O}$ que, em conjunto com La e Ce, pode estar indicando presença de monazita e, portanto, de áreas fonte ricas em rochas félsicas. A dispersão dos valores de Ba pode estar ligada à quantidade maior ou menor de feldspatos potássicos de amostra para amostra, o que é coerente com os estudos petrográficos. O Sr é muito variável, o que poderia estar indicando graus diferenciados de intemperismo nas áreas fonte ou quantidades variáveis de plagioclásio e carbonato de $\mathrm{Ca}$ nos metassedimentos analisados. Normalmente este elemento é lixiviado meta Notar que seus valores são baixos em sedimentos de MP e altos em OIP, AIO e AIM. Para testar este problema, o grau de intemperismo das áreas-fontes das rochas metassedimentares do Grupo Ibiá foi avaliado através do CIA (Indice Químico de Alteração: $\left[\mathrm{Al}_{3} \mathrm{O}_{3} /\left(\mathrm{Al}_{2} \mathrm{O}_{3}\right.\right.$ $\left.\left.+\mathrm{CaO}+\mathrm{Na}_{2} \mathrm{O}+\mathrm{K}_{2} \mathrm{O}\right)\right] \times 100$, Nesbitt e Young 1982). Os valores do CIA para os metassedimentos do Grupo Ibiá variam de 57 a 74 (granito fresco $=45$ a 55), com média de 65 para nove amostras analisadas, 0 que sugere fraco intemperismo químico nas áreas-fonte. O Sr é mais elevado nas amostras com CIA mais baixo, o que reforça que suas concentrações são diretamente proporcionais ao grau de intemperismo nas áreas-fonte.

O padrão de distribuição dos ETR também fornece alguns dados adicionais quando comparado com padrões de folhelhos e grauvacas e rochas sedimentares de diversos ambientes tectônicos (Fig. 7).

O padrão geral é de depleção em ETR pesados (ETRP) $\left(\mathrm{La}^{*} / \mathrm{Yb} *=\right.$ 13,$6 ; *$ normalização pela crosta superior) o que coincide com o comportamento geral de folhelhos e grauvacas (Henderson, 1984). O padrão de distribuição dos ETRP é uniforme para as nove amostras do Grupo Ibiá, variando apenas as concentrações, enquanto que para os ETR leves (ETRL) não há esta uniformidade. Duas amostras apresentam forte anomalia negativa para Nd e valores altos para La e ETRP. Estas diferenças são contraditórias, mas podem estar refletindo complexas misturas de detritos de diferentes rochas. Leves anomalias negativas de Eu em algumas amostras denunciam contribuição de áreas fonte graníticas, comportamento similar ao da Suite de Hodgkinson (MCA, Bhatia e Crook 1986) e de grauvacas em geral. Henderson (1984) destaca o fato de que sedimentos do Arqueano têm anomalia positiva de $\mathrm{Eu}$, enquanto que os folhelhos proterozóicos não mostram esta anomalia, demonstrando mudança no comportamento composicional crustal com o passar do tempo. Já a média dos folhelhos norte-americanos (Fanerozóicos) apresenta anomalia negativa de Eu e Ho. Os metassedimentos do Grupo Ibiá apresentam anomalia positiva de Ho. As variações apresentadas pelos metassedimentos do Grupo Ibiá são creditadas a misturas de detritos de 
Composição isotópica das rochas de arco de Arenópolis e Mara Rosa (Pimentel et al., 1999)

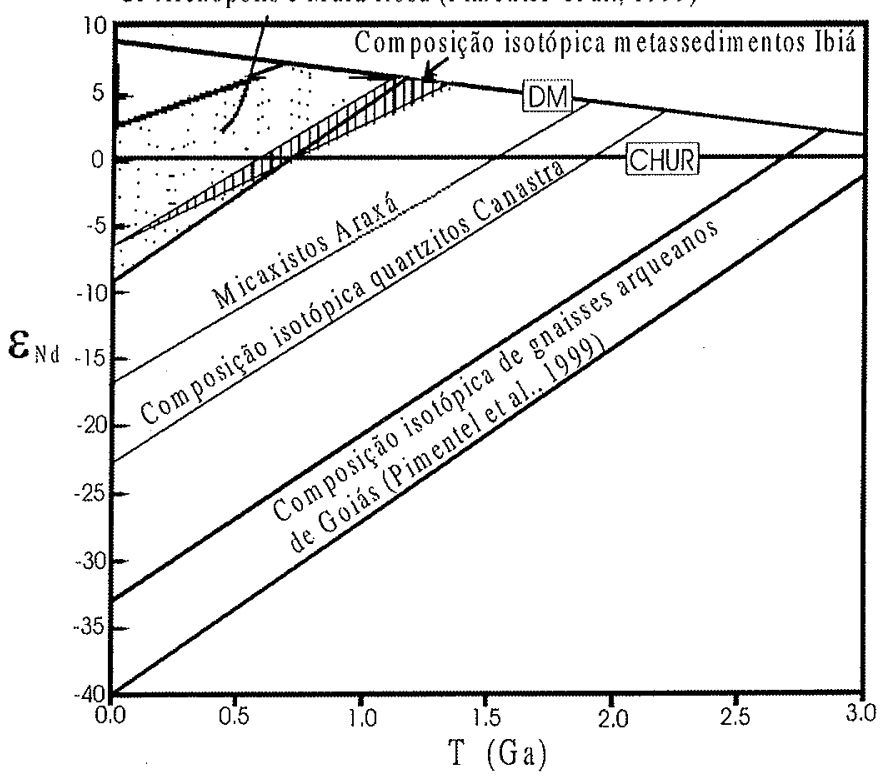

Figura 8-Composição isotópica de Nd dos metassedimentos do Grupo lbiá em comparação com a composição isotópica dos arcos magmáticos de Goiás, micaxistos do Grupo Araxá e quartzitos do Grupo Canastra (construído a partir de dados de Pimentel et al. 1999b e Seer 1999).

\section{diferentes tipos de áreas fonte, ora máficas, ora félsicas.}

Estas características aliadas aos demais aspectos petrográficos destas rochas permitem supor que elas foram geradas por aportes de detritos de ciclo sedimentar primário, com pouco retrabalhamento. Segundo Cox e Lowe (1995), argilitos depositados durante as fases iniciais de formação crustal apresentam composições mistas devido a variações composicionais nas áreas fonte. Além disso, argilas recicladas tendem a ter elevados teores de $\mathrm{K}_{2} \mathrm{O}$ (5 a $10 \%$ ), diferindo dos valores mais baixos dos metassedimentos do Grupo Ibiá.

ISÓTOPOS Sm-Nd Com a finalidade de complementar os dados obtidos através de trabalhos de campo, estudos petrográficos e geoquímicos, já descritos, utilizou-se o método isotópico Sm-Nd. Os recursos do método Sm-Nd possibilitam uma avaliação das idades modelo das litologias do Grupo Ibiá e dão uma idéia sobre as características das áreas-fonte dos sedimentos. Três amostras de rocha total de calcifilito do Grupo Ibiá foram analisadas no Laboratório de Geocronologia da Universidade de Brasília.

Como já discutido, as rochas metassedimentares do Grupo Ibiá originaram-se em área fonte onde predominavam rochas ígneas félsicas e máficas e sua deposição deu-se de modo rápido e sem retrabalhamento posterior, com base no elevado conteúdo de feldspatos. Seu metamorfismo não ultrapassou a zona da clorita da fácies xisto verde. Deste modo supõe-se que seu soterramento não tenha sido expressivo. Além dos aspectos geológicos e petrográficos, os dados de geoquímica de rocha total indicam áreas-fonte em arco magmático. Sendo formadas de partículas minerais derivadas por erosão e intemperismo de rochas dominantemente vulcânicas e plutônicas suas composições isotópicas de Sm e Nd serão influenciadas não apenas pela evolução dos sedimentos até seu posicionamento final, mas também pelas composições de suas áreas-fonte. As idades modelo para os metassedimentos do Grupo Ibiá variam de 1,16 a $1,33 \mathrm{Ga}$ para três amostras (Tab. 4).

Segundo Faure (1986) as idades modelos de folhelhos são similares às idades de rochas ígneas e metamórficas das quais eles derivaram e, por consequência, as idades Sm-Nd dos sedimentos comumente excedem suas idades deposicionais. Nas rochas sedimentares detríticas as idades modelo devem ser tratadas como idades de residência crustal. As idades de residência crustal de folhelhos proterozóicos e fanerozóicos são geralmente mais antigas do que suas idades deposicionais. Isto permite supor que eles são formados por material crustal reciclado separado a longo tempo do Reservatório Condrítico
Uniforme (CHUR). No entanto, a diferença entre a idade de residência crustal e a idade de deposição decresce se sedimentos detríticos vulcanogênicos, representando eventos magmáticos durante episódios orogenéticos, são misturados a sedimentos detríticos mais antigos durante a deposição. Os dados obtidos para a região de Araxá confirmam o fato de que houve pouca contribuição sedimentar de áreas-fontes mais velhas que $1,3 \mathrm{Ga}$ nestes sedimentos. Além disso, o tempo de residencia crustal dos materiais que formaram os metassedimentos deve ter sido relativamente baixo uma vez que os valores de $\varepsilon_{\text {NdT }}$ variam de $-0,11$ a $-0,93$. Deste modo, eles foram formados a partir de áreas-fontes mais jovens, com pouca residência crustal.

No contexto geológico regional, as áreas fonte possíveis seriam a suposta existência de um arco magmático localizado a sudoeste de Araxá, região coberta pelas rochas fanerozóicas da Bacia do Paraná, ou os arcos magmáticos neoproterozóicos de Arenópolis, Bom Jardim e Iporá localizados no oeste de Goiás (Pimentel et al. 1999b) e que podem ter continuidade para sudeste, ou mesmo, os arcos magmáticos relacionados ao Maciço de Guaxupé (Mercosul 1998). A similaridade de composição isotópica entre os metassedimentos do Grupo Ibiá e arcos magmáticos de Goiás é notável (Fig. 8).

Os metassedimentos do Grupo Araxá têm idade modelo de 1,94 Ga, portanto bem mais velha do que a dos metassedimentos do Grupo Ibiá (Seer 1999). Os metasedimentos do Grupo Araxá devem ter se formado a partir da mistura de detritos sedimentares oriundos de fontes mais jovens que a idade modelo e de fontes mais velhas. Estas últimas estariam situadas em área continental, enquanto as primeiras devem corresponder às rochas mais jovens dos arcos magmáticos de Goiás. $\mathrm{O}$ valor de $\varepsilon_{\text {NGT }}$ é - 10,21 e indica maior residência crustal para os metassedimentos do Grupo Araxá em relação aos do Grupo Ibiá. No entanto, em outros locais da Faixa Brasília, os metassedimentos do Grupo Araxá apresentam bimodalidade, ora com idades modelo Sm$\mathrm{Nd}$ mais velhas, ora mais novas, similares às dos metassedimentos Ibiá (Pimentel et al. 1999a).

Para o Grupo Canastra a idade modelo é 2,2 Ga e o $\varepsilon_{\text {NdT }}=-12,77$ (Brod 1999), indicando predomínio de áreas-fonte mais antigas e residência crustal maior do que as do Grupo Araxá e Ibiá. Estas interpretações são compatíveis com as interpretações a respeito dos paleoambientes da unidade Canastra, que são relacionados a sequências regressivas de plataforma continental, situada na borda da massa continental paleoproterozóica-arqueana do São Francisco, principal área-fonte destes sedimentos.

Estes fatos levantam duas revisões importantes de propostas anteriores: a) a existência de discordância erosiva (Pereira 1992) entre os Grupos Ibiá e Canastra, na região de Coromandel (MG), pode ser questionada na região de Araxá e b) o Grupo Canastra não serviu como área fonte importante para o Grupo Ibiá pelo menos na região de Araxá, que é sua área-tipo.

\section{- GRUPo IBIÁ COMO UM tERRENo tectono-} ESTRATIGRÁFICO A compreensão da história de um cinturão orogênico envolve todos os elementos geológicos, mas, basicamente, compreende uma integração dos dados estratigráficos com a geologia estrutural (Howell 1993). Os dados estratigráficos fornecem informação a respeito da paleogeografia e idades das unidades de um cinturão orogênico. Os dados estruturais descrevem a configuração destas unidades. Segundo Howell (1993), um cinturão orogenético é essencialmente um quebra-cabeças formado por uma coleção de peças crustais. Para reconstruir a sequência de eventos que originaram um cinturão orogênico deve-se identificar as peças fundamentais que compõem o quebra-cabeças. A cada uma destas peças denomina-se terreno tectonoestratigráfico: "um conjunto de rochas limitado por falhas, com uma estratigrafia distinta, que caracteriza um ambiente geológico particular" (Howell 1993). Esta definição implica em que determinado terreno tectonoestratigráfico não tem relações genéticas com terrenos vizinhos.

Os dados aqui apresentados para o Grupo Ibiá e a inexistência de relações genéticas com os grupos Araxá e Canastra demonstram que ele tem arranjo litoestratigráfico interno próprio, reflexo de seu ambiente tectônico-sedimentar e está limitado por zonas de cisalhamento subhorizontais e subverticais ( Seer 1999). Portanto, com base na definição de Howell (1993), esta unidade geológica pode ser tratada como um terreno tectonoestratigráfico. Esta proposição se contrapõe às concepções anteriores ( Barbosa et al. 1970, Paulsen et al. 1974, Ferrari 1989), que assumem que as diversas unidades estratigráficas 
podem representar transições ou fácies umas das outras. No presente trabalho, visualiza-se uma elevada mobilidade das diversas unidades sem vínculos genéticos aparentes entre si, que seriam oriundas, por aloctonia tectônica, de regióes geográficas distintas. Neste sentido, os grupos Araxá e Canastra também podem ser tratados como terrenos tectonoestratigráficos (Seer 1999) e a metodologia baseada no conceito de terrenos tectonoestratigráficos pode ser aplicada na Faixa Brasília.

CONCLUSÕES O Terreno Ibiá mostra forte vínculo genético com áreas fonte relacionadas à arcos magmáticos e foi gerado, possivelmente, num contexto sedimentar que envolveu correntes de turbidez (distais?). Suas idades modelo de 1,1 a $1,33 \mathrm{Ga}$, indicam áreas fonte mais jovens do que as dos terrenos Araxá e Canastra. Os baixos valores de $\varepsilon_{\text {at }}(-0,11$ a $-0,93)$ implicam em sedimentos com pouco tempo de residência crustal, possivelmente de ciclo sedimentar primário. Estes fatos estão em concordância com os dados petrográficos e geoquímicos. Este terreno não mostra nenhuma relação genética com os terrenos Canastra e Araxá e não tem quaisquer vínculos com áreasfonte mais antigas ligadas ao massas continentais paleoproterozóicasarqueanas. É um terreno ligado geneticamente aos arcos magmáticos do oeste de Goiás, ou a arcos magmáticos situados sob a cobertura fanerozóica representada pela Bacia do Paraná ou no Maciço de Guaxupé. Pimentel et al. (1999b) concluem que a longa história do magmatismo de arco, entre 0,85 a $0,63 \mathrm{Ga}$, sugere que durante a maior parte deste intervalo de tempo, a margem oeste da massa continental do São Francisco fazia face a uma bacia oceânica, onde arcos-de-ilhas intraoceânicos foram formados e acrescidos uns aos outros e/ou soldados à margem continental. Estes fatos implicam também na possibilidade de que a bacia oceânica localizada entre os arcos magmáticos e a margem do continente São Francisco tenha características de bacia de retroarco, com subducção de oeste para leste. Assim, o Terreno Ibiá representaria o aporte de detritos oriundos deste arco num contexto basinal de retroarco.

Agradecimentos Este trabalho é parte da Tese de Doutorado do primeiro autor que agradece à CAPES pela concessão de uma bolsa de doutoramento. Os autores são gratos ao Instituto de Geociências da UnB pelo suporte laboratorial e a dois revisores anônimos da RBG pela revião crítica do manuscrito.

\section{Referências}

Barbosa O. 1955. Guia de Excursões. In: Congr. Bras. Geol., 9, 1955. São Paulo SBG. Noticiário $3: 3-5$

Barbosa O., Braun O.P.G., Dyer R.C., Cunha C.A.B.R. 1970. Geologia da região do Triângulo Mineiro. Rio de Janeiro. DNPM/DFPM, 140p. (Boletim 136)

Besang C., Eberle W., Lahner L., Lenz H., Mollat H., Müller P., Paulsen S. 1977. Datação radiométrica en rochas de MG e ES. Belo Horizonte. CPRM, $41 \mathrm{p}$.

Bhatia M.R. 1983. Plate tectonics and geochemical compositions of sandstones. J. Geol., $91: 611-627$

Bhatia M.R. \& Crook K.A.W. 1986. Trace element characteristics of graywackes and tectonic setting

Braun O.PG \& Baptista M B. 1978 Consideracões sobre a geologia pré-cambriana da região sudeste e parte da regiäo centro-oeste do Brasil. Salvador. SBG/Núcleo região sudeste e parte da região cent

Brod J.A. 1999. Petrology and geochemistry of the Tapira Alkaline Complex, Minas Ge. A. 1999. Petrology and geochemistry of the Tapira, PhD Thesis. 486p.

Cox R. \& Lowe D. R. 1995. A conceptual review of regional controls on the composition of \& Lowe D.R. 1995. A conceptual review of regional controls on the composition of
clastic sediment and the co-evolution of continental blocks and their sedimentary cover. J. Sedim. Res., A65(1):1-12

Faure G. 1986. Principles of isotope geology. New York. John Wiley \& Sons. 586p.

Ferrari P.G. 1989. A Formação Ibiá e sua pertinência ao Grupo Araxá. In: SBG, Simp. Geol. Minas Gerais, 5, Belo Horizonte, Anais, 257-261

Floyd P.A., Shail R., Leveridge B.E., Franke W. 1991. Geochemistry and provenance of Rhenohercynian synorogenic sandstones: implications for the tectonic environment discrimination. In A.C. Morton, S.P. Todd \& P.D.W. Haughton (eds), Developments discrimination. In: A.C. Morton, S.P. Todd Q.D.W. Haughton 57:173-188

Fuchtbauer $\mathrm{H}$. 1974. Sediments and sedimentary rocks I. John Willey \& Sons, Inc. New York. 463p.

Henderson P. 1984. Rare earth element geochemistry. Amsterdan. Elsevier. 510p.

Howell D.G. 1993. Tectonics of supect terranes - mounfain building and continental growth. Londres. Chapman \& Hall. 231 .

Kearey \& Vine FJ 1996. Global Tectonic. Blackell Science Ltd. Oxford. 333p

Magalhães P.M. 1989. Análise estrutural qualitativa das rochas do Grupo Bambui na porção sudoeste da Bacia do São Francisco. DEGEO-EM, Universidade Federal de Ouro Preto, Ouro Preto, Dissertação de Mestrado, 100p.
Mercosul 1998. Mapa de Integração Geológica da Bacia do Prata e Áreas Adjacentes.

Mercado Comum do Sul, Boletim de Lançamento, 1998. Buenos Aires from major element chemistry of lutites. Nature, 299:715-717

Pau A., A Bicalho F.D., Ferrari P.G., Heineck C., Steiner H.P., Paulino J., Richter P., A.A., Bicalho F.D., Ferrar L., Mollat H., Resch M., Ostwald J., Jochmann D. 1974. Relatório de recoLahner L., Mollat $\mathrm{H}$., Resch M., Ostwald J., Jochmann D. 974 . Relatoro de recoMhecimento geológico-geoguimico Pratinha-Argenita-Tapira-Serra da Canastra, Minas Gerais. Rio de Janeiro. CPRM/DNPM/Serviço Geológico da República Fe-
deral da Alemanha, 57p.

Pereira L.F. 1992. Relaçôs rectono-estratigráficas entre as unidades Canastra e Ibiá no regiäo de Coromandel e Guarda-Mor; MG. IGC, Universidade de Brasília, Brasília, Dissertação de Mestrado, 75p.

Pereira L.F., Dardenne M.A., Souza J., Alburquerque M. 1992. A Formação Ibiá entre Coromandel e Guarda-Mor, MG. Rev. Esc. Minas, 45:83-84

Pettijohn F.J. 1975. Sedimentary rocks. Harper \& Row Publishers. New York. 628p.

Pimentel M.M. Dardenne M. Viana M.G., Gioia S.M.C.L., Seer H.J. 1999a. Nd isotopes and the provenance of sediments of the Brasilia Belt, central Brazil, In: Simp. SulAmericano de Geol. Isotóp., 2, Cordoba, Actas, 426-429

Pimentel M.M., Fuck R.A., Botelho N.F. 1999b. Granites and the geodynamic history of the Neoproterozoic Brasilia Belt, Central Brazil: a review. Lithos, 46:1-21

Seer H.J. 1999. Evolução tectônica dos Grupos Araxá, Ibiá e Canastra na Sinforma de Araxá, Minas Gerais. IGC, Universidade de Brasília, Brasília, Tese de Doutorado,

Simões L.S.A \& Navarro G, 1996. Estruturação da Faixa Brasília na regiño de Araxá, MG. In: SBG, Congr. Bras. Geol., 39, Salvador, Anais, 92-95

Simões L.S.A. \& Navarro G. 1997. Caracterização cinemática da Zona de Cisalhamento da Bocaina, Ataxá, MG. In: SBG, Simp. Nac. Est. Tect., 6, Pirenópolis, Ancis. 269-271 Tucker M.E. 1985. Sedimentary petrology - an introduction. Oxford, Blackwell Scientitic Publications, 252p

Manuscrito A-1134 Recebido em 5 de novembro de 1999 Reyisão dois autores em 30 de março de 2000 Revisão aceita em 10 de abril de 2000 